\title{
Development of a multiplex PCR for identification of mastitis causing organisms
}

\author{
Karanvir Singh, Mudit Chandra, Gurpreet Kaur, Deepti Narang, DK Gupta, AKArora and NS Sharma
}

Received: 14 October 2018 / Accepted: 10 January 2019 / Published online: 18 April 2019

(c) Indian Dairy Association (India) 2019

\begin{abstract}
In the present study, a de novo multiplex polymerase chain reaction using genus specific primers for four organisms' viz., E. coli, Klebsiella pneumoniae, Staphylococcus aureus and Streptococcus agalactiae were designed to identify and differentiate all the four organisms in a single reaction. Further, DNA was extracted from mastitic milk using three different methods and was subjected to multiplex polymerase chain reaction to compare and identify the best method out of these three methods based on the amplification results of multiplex polymerase chain reaction. It was observed from the study that multiplex PCR was able to amplify three organisms (Streptococcus agalactiae, Klebsiella pneumoniae and E. coli) successfully whereas was unable to amplify Staphylococcus aureus in the multiplex PCR. Mutiplex PCR when evaluated on the field samples using mastitic milk revealed SDS Triton DNA extraction method to be superior to Power Food Microbial DNA isolation Kit and Milk Bacterial DNA isolation kit method in isolating the bacterial DNA from the mastitic milk as indicated by amplification in multiplex PCR reaction.
\end{abstract}

Keywords: Mastitis, Milk, DNA, Multiplex PCR

Karanvir Singh

Department of Veterinary Microbiology, College of Veterinary Science, Guru Angad Dev Veterinary and Animal Sciences University, Ludhiana Punjab 141004, India

Mudit Chandra $(\square)$

Department of Veterinary Microbiology, College of Veterinary Science, Guru Angad Dev Veterinary and Animal Sciences University, Ludhiana Punjab 141004, India

E-mail: drmuditchandra@,rediffmail.com, Phone No.. 0161-2414033; Fax no. 0161-2400822

Gurpreet Kaur, Deepti Narang

Department of Veterinary Microbiology, College of Veterinary Science, Guru Angad Dev Veterinary and Animal Sciences University, Ludhiana Punjab 141004, India

\section{Introduction}

Mastitis is one of the most commonly occurring diseases of dairy animals. It is the most important cause of economic losses to the dairy industry throughout the world including India (Miller et al., 1993). It is the inflammation of the udder characterized by pathological changes in the mammary gland tissue and also in the physical and chemical properties of milk (Radostitis et al., 2000). There are more than 150 bacterial species implicated in the mastitis and broadly they have been categorized into three major types; environmental, contagious and opportunist (Kuang et al., 2009).

Primarily diagnosis for mastitis is based on the physiological symptoms visible to naked eyes, such as swelling and inflammation of the mammary gland or the apparent changes in the milk. Because, such symptoms appear only at the chronic or clinical state of mastitis, its earlier diagnosis relies on many simple diagnostic test procedures. Among the diagnostic procedures commonly employed are the measurement of somatic cell count and enzymatic analysis. But these simple and efficient methods too have discrepancies which could increase likelihood for false positive or false negative results. Extensive knowledge of the etiology of mastitis is fundamental for the development of an efficient diagnostic test as well as control of the disease and isolation of bacteria from the mastitic milk sample is considered to be the definitive diagnosis (gold standard). Though, isolation

\section{K Gupta}

Department of Veterinary Clinical Medicine, College of Veterinary Science, Guru Angad Dev Veterinary and Animal Sciences University, Ludhiana Punjab 141004, India

\section{A K Arora and N S Sharma}

Department of Veterinary Microbiology, College of Veterinary Science, Guru Angad Dev Veterinary and Animal Sciences University, Ludhiana Punjab 141004, India 
is considered gold standard but it includes the use of selective/ differential media and inoculating milk on it for a definitive time and further subjected to biochemical test for identification of the bacteria. Since, these traditional methods are gold standard but often very much time consuming. With the invention of polymerase chain reaction (PCR) there is a revolution in the field of disease diagnosis (Geha et al., 1994). PCR detects DNA sequences that are unique to a species or group of organisms thus confirming the presence and absence of bacterial DNA from both the viable as well as non viable organisms. In multiplex two or more loci are simultaneously amplified in the same reaction tube. Amplifying more than one locus in the same reaction (multiplex PCR) is becoming a rapid and convenient screening assay in both the research and the clinical laboratories. It has previously been shown that milk samples could serve as a source for the amplification of specific DNA sequences using PCR (Lipkin et al., 1993; Berri et al., 2000). Keeping in view of the above facts, the present study was designed with the objective to develop and evaluate a multiplex PCR on field samples (milk) collected from mastitic animals.

\section{Materials and methods}

\section{Sampling}

A total of sixty nine milk samples (15-20ml) from mastitic animals (subclinical and clinical cases) were collected aseptically (after discarding first few streaks of milk) from the Veterinary Clinical Complex, GADVASU, Ludhiana and also from nearby dairy farms in and around Ludhiana. These samples were kept on ice and transferred immediately to the laboratory. Milk samples were subjected to isolation of bacteria using blood agar and Brain Heart infusion agar and were preserved at $-20^{\circ} \mathrm{C}$ for extraction of DNA. Fifty milk samples that yielded bacterial growth were selected for DNA extraction.

\section{Standard cultures}

Standard culture of Staphylococcus aureus (MTCC 902), Streptococcus pyogenes (MTCC 442), Escherichia coli (MTCC 901) and Klebsiella pneumoniae (MTCC 432) were procured from Microbial type culture collection (MTCC), Chandigarh. These cultures were revived on blood agar/brain heart infusion agar and checked for cultural as well as biochemical characters and stored on trypticase soy agar slant at $4^{\circ} \mathrm{C}$ for further use.

\section{Extraction of DNA from the standard cultures}

The extraction of bacterial genomic DNA was done using phenol: chloroform: isoamyl alcohol (25:24:1) (PCI) as per the method of Sambrook and Russell (2001). In brief, $1.8 \mathrm{ml}$ of overnight grown bacterium in LB broth was centrifuged and to the pellet, $50 \mu 1$ each of $10 \%$ SDS (Sodium Dodecyl Sulphate) and Proteinase K $(200 \mu \mathrm{g} / \mathrm{ml})$ were added and incubated at $60^{\circ} \mathrm{C}$ for $1 \mathrm{~h}$. Next, $500 \mu \mathrm{l}$ of phenol:chloroform:isoamyl alcohol (PCI; 25:24:1) was added to it, mixed gently and centrifuged $(10,000 \mathrm{~g})$ for 10 minutes to collect the supernatant and the step was repeated. To the supernatant equal volume of Isopropanol and to the one-tenth volume of supernatant, 3M Sodium acetate ( $\mathrm{pH}-5.2)$ was added and kept at $-20^{\circ} \mathrm{C}$ for overnight. Next day, the precipitated DNA was collected after centrifuging $(10,000 \mathrm{~g})$ for 20 minutes. DNA was washed twice with $500 \mu 1$ of $70 \%$ ethanol and after removal of residual ethanol it was reconstituted to $50 \mu 1$ by adding nuclease free water (NFW) and stored at $-20^{\circ} \mathrm{C}$ for further use.

\section{Extraction of the DNA from the milk}

The DNA was extracted from the milk using three methods viz., SDS-Triton method (Kour et al., 2017), Power food Microbial DNA isolation Kit (Mo Bio Laboratories, Inc. USA) and Milk Bacterial DNA isolation Kit (Norgen Biotek Corp., Canada).

\section{SDS-Triton method}

In brief one $\mathrm{ml}$ each of $10 \%$ SDS and $20 \%$ Triton-X-100 was added to eight $\mathrm{ml}$ of milk and incubated at $60^{\circ} \mathrm{C}$ for $1 \mathrm{~h}$ to remove or lessen the fat/cream layer. Later, $1.8 \mathrm{ml}$ milk was transferred and subjected to isolation of DNA as per the method using phenol:chloroform:isoamyl alcohol (PCI) Sambrook and Russell (2001). After extraction, optical density (OD) at 260 and $280 \mathrm{~nm}$ of individual sample was measured using Nano drop (Thermo Scientific, USA). A ratio of 1.7 to $1.9(260 / 280)$ was considered satisfactory and stored at $-20^{\circ} \mathrm{C}$ for further use.

\section{Extraction of DNA from milk using kits}

The DNA from the milk was extracted using Power food Microbial DNA isolation Kit (Mo Bio Laboratories, Inc. USA) and Milk Bacterial DNA isolation Kit (Norgen Biotek Corp., Canada) as per the manufacturer's instructions.

\section{Polymerase chain reaction (PCR) to standardize individual genus}

PCR was carried out using genus specific primers for E. coli, Klebsiella, Staphylococcus and Streptococcus (Table 1) which were designed using Primer 3 Software (Untergasser et al., 2012) and tested in silico. A reaction mixture consisting of $2.5 \mu 1$ of $10 \mathrm{X}$ PCR buffer (New England Biolabs Inc., USA), $1 \mu 1$ of $20 \mathrm{pmol} / \mu 1$ of each forward and reverse primers (Flarebio Biotech Inc., China), $0.6 \mu 1$ of $50 \mathrm{mM} \mathrm{MgCl}_{2}$ (New England Biolabs Inc., USA), $1 \mu 1$ of 10 $\mathrm{mM}$ dNTPs mix (New England Biolabs Inc., USA), $0.2 \mu \mathrm{l}$ of $5 \mathrm{U} / \mu 1$ of Taq DNA polymerase (Genxbio Health Sciences Pvt. Ltd., India), $2 \mu 1$ of individual template DNA containing approximately $100 \mathrm{ng}$ of DNA and the reaction volume was made to $25 \mu 1$ by adding nuclease free water (New England Biolabs Inc., USA). PCR was performed on a thermocycler (Veriti, ABI, USA) with the following conditions; an initial denaturation at $94^{\circ} \mathrm{C}$ for 5 minutes and 35 cycles each of denaturation at $94^{\circ} \mathrm{C}$ for 45 seconds, annealing at $60^{\circ} \mathrm{C}$ for E. coli, Klebsiella, Staphylococcus and Streptococcus for 1 minute and extension at $72^{\circ} \mathrm{C}$ for 1 minute. This was followed 
by a final extension at $72^{\circ} \mathrm{C}$ for 10 minutes. The products were run on $1.5 \%$ agarose along with $100 \mathrm{bp}$ DNA molecular weight marker (New England Biolabs, USA) at $5 \mathrm{~V} / \mathrm{cm}$ and visualized using gel documentation system (AlphaImager, Alpha Innotech, USA).

\section{Standardization of Multiplex PCR (MPCR) using standard cultures}

For MPCR, $25 \mu$ reaction mixture consisting of $2.5 \mu$ l of $10 X$ PCR buffer (New England Biolabs Inc., USA), $1 \mu 1$ of $20 \mathrm{pmol} / \mu 1$ of each forward and reverse primers (Flarebio Biotech Inc., China), $1.0 \mu \mathrm{l}$ of $50 \mathrm{mM} \mathrm{MgCl}_{2}$ (New England Biolabs Inc., USA), $0.5 \mu \mathrm{l}$ of $10 \mathrm{mM}$ dNTPs mix (New England Biolabs Inc., USA), $0.2 \mu 1$ of $5 \mathrm{U} /$ $\mu l$ of Taq DNA polymerase (Genxbio Health Sciences Pvt. Ltd., India), $8 \mu$ l of template DNA ( $2 \mu$ l each from all the four bacterial strain) and the reaction volume was made to $25 \mu \mathrm{l}$ by adding nuclease free water (New England Biolabs Inc., USA). MPCR was performed on a thermocycler (Veriti, ABI, USA) with the following conditions; an initial denaturation at $94^{\circ} \mathrm{C}$ for 5 minutes and 35 cycles each of denaturation at $94^{\circ} \mathrm{C}$ for 45 seconds, annealing at $60^{\circ} \mathrm{C}$ for 1 minute and extension at $72^{\circ} \mathrm{C}$ for 1 minute. This was followed by a final extension at $72^{\circ} \mathrm{C}$ for 10 minutes. The products were run on $1.5 \%$ agarose along with 100 bp DNA molecular weight marker (New England Biolabs, USA) at $5 \mathrm{~V} / \mathrm{cm}$ and visualized using gel documentation system (AlphaImager, Alpha Innotech, USA).

\section{MPCR directly testing on milk}

For this, $25 \mu \mathrm{l}$ reaction mixture consisting of $2.5 \mu \mathrm{l}$ of $10 \mathrm{X}$ PCR buffer (New England Biolabs Inc., USA), $1 \mu 1$ of $20 \mathrm{pmol} / \mu 1$ of each forward and reverse primers (Flarebio Biotech Inc., China), $1.0 \mu \mathrm{l}$ of $50 \mathrm{mM} \mathrm{MgCl}_{2}$ (New England Biolabs Inc., USA), $0.5 \mu \mathrm{l}$ of $10 \mathrm{mM}$ dNTPs mix (New England Biolabs Inc., USA), $0.2 \mu \mathrm{l}$ of $5 \mathrm{U} / \mu \mathrm{l}$ of Taq DNA polymerase (Genxbio Health Sciences Pvt. Ltd., India), $10.0 \mu \mathrm{l}$ of DNA extracted directly from milk using three methods and the reaction volume was made to $25 \mu \mathrm{l}$ by adding nuclease free water (New England Biolabs Inc., USA). MPCR was performed on a thermocycler (Veriti, ABI, USA) with the following conditions; an initial denaturation at $94^{\circ} \mathrm{C}$ for 5 minutes and 35 cycles each of denaturation at $94^{\circ} \mathrm{C}$ for 45 seconds, annealing at $60^{\circ} \mathrm{C}$ for 1 minute and extension at $72^{\circ} \mathrm{C}$ for 1 minute. This was followed by a final extension at $72^{\circ} \mathrm{C}$ for 10 minutes. The products were run on $1.5 \%$ agarose along with $100 \mathrm{bp}$ DNA molecular weight marker (New England Biolabs, USA) at $5 \mathrm{~V} / \mathrm{cm}$ and visualized using gel documentation system (AlphaImager, Alpha Innotech, USA).

\section{Results and discussion}

\section{Development of MPCR}

Primers initially were used individually on the standard bacterial DNA procured from MTCC, Chandigarh. Once the individual primers gave the desired amplicon they were used for multiplexing. Various combination of DNA template volume 1-10 $\mu$ l, Magnesium chloride ( $50 \mathrm{mM})$ 0.5-1.5 $\mu \mathrm{l}$, Taq DNA polymerase $(5 \mathrm{U} / \mu \mathrm{l})$ 0.2-0.5 $\mu 1$, and annealing time $(45-60 \mathrm{sec})$ and temperature $\left(55-60{ }^{\circ} \mathrm{C}\right)$ combinations were tried to standardize a single multiplex PCR to identify all the four etiological agents simultaneously. After conducting various experiments we could finalize a DNA template volume of $10 \mu \mathrm{l}$, Magnesium chloride $1 \mu \mathrm{l}$, Taq DNA polymerase $0.2 \mu \mathrm{l}$, and annealing time of 60 seconds at $60^{\circ} \mathrm{C}$ for 35 cycles to be used in MPCR.

In this study we could multiplex three organisms viz., Streptococcus, Klebsiella and E. coli in a single reaction. However, Stapylococcus could not be combined in this PCR, though we tried to vary initial template of Staphylococcus in both increasing and decreasing direction (Fig a).

\section{Evaluation of three different methods for extracting DNA from milk}

DNA was extracted directly from milk using three methods, SDSTriton DNA extraction method, Power Food Microbial DNA isolation kit and Milk bacterial DNA isolation kit. The bacterial DNA extracted from all the three methods was subjected to multiplex PCR using genus specific primers (E. coli, Klebsiella, Staphylococcus and Streptococcus) to compare and identify the best method out of the three and it was observed that with the help of first method i.e. SDS Triton DNA extraction method, we got $100 \%$ bacterial DNA from milk as was amplified via multiplex PCR and with the help of second method we could achieve $60 \%$ success whereas with the help of third method we could only achieve a $16 \%$ rate of success (Table 2 ).

\section{Evaluation of MPCR on field samples}

Multiplex PCR was tested on fifty mastitis (clinical/subclinical) milk samples after extracting DNA from these using all the three methods and it was found that DNA extracted from milk gave positive amplification indicating success of the multiplex PCR on the field samples.

Mastitis is characterized by an increase in somatic cells, especially leukocytes, in the milk and by pathological changes in the mammary tissue (Ranjan et al., 2010). It is an economically devastating disease faced by the dairy industry worldwide and it is estimated that $70 \%$ of all the avoidable losses in dairy production are accounted to mastitis. Microbial culturing is considered the most suitable, accurate and reliable method to confirm the causative organisms and many investigations had assured that bacterial culturing is the gold standard method for identifying intramammary infections and for developing a specific mastitis control program for a dairy herd.

Due to the limitation of cultural methods, the development of PCR based methods provides a good option for quicker 
identification of infectious agent. PCR based method is rapid as identification of bacterial pathogen can be done in hours rather than days. PCR can also improve the level of detection due to its higher sensitivity. The presence of pathogens may be detected at earlier stages of infection and in carrier animals when the number of bacteria in milk may be very low (Brikenmeyer and Mushahwar, 1991). The use of PCR detection and identification test for mastitis pathogens that produced results in a day are specific, sensitive and cheap (Khan et al., 1998).

Primers were designed for simultaneous identification of four most common organisms causing mastitis. Whole genome sequence was downloaded from the GenBank database from the public domain. The genomes were analyzed to find regions having capability to simultaneously differentiate four organisms from rest of the organisms as well as to differentiate with one another too. For developing a MPCR it was essential that the amplicons besides being specific should differ in length by at least 50 base pair from each other so that they could be clearly distinguishable on agarose gel electrophoresis. Primers were designed keeping all the above parameters and checked insilico to observe their characters of specificity as well as $\mathrm{G}+\mathrm{C}$ percentage and the primers once fulfilling most of the characters were synthesized and used in the multiplex PCR.

After the successful individual amplification we could multiplex three organisms Streptococcus, Klebsiella, E.coli in a single multiplex PCR. However, Staphylococcus could not be combined in multiplex PCR. Though we tried to vary initial template of Staphylococcus in both direction i.e. increasing and decreasing concentration of Staphylococcus DNA template in multiplexing PCR but we could not achieve success to amplify all four etiological agents in single multiplex PCR. Multiplex PCR has been developed for use on milk samples by various earlier workers;
Shome et al. (2011) developed and evaluated a multiplex PCR for simultaneous detection of ten bacterial species causing bovine mastitis namely, Staphylococcus aureus, Staphylococcus chromogenes, Staphylococcus epidermidis, Staphylococcus sciuri, Staphylococcus haemolyticus, Staphylococcus simulans, Streptococcus agalactiae, Streptococcus dysgalactiae, Streptococcus uberis and Escherichia coli in milk. The developed MPCR was found to be simple, rapid, reliable and specific in species identification of 10 bacteria at a time which is partially similar to the findings of this study where multiplex for three organisms only was achieved whereas Staphylococcus aureus could not be combined in the multiplex PCR. Gaddi et al. (2016) developed multiplex PCR for detection of $S$. aureus, $E$. coli, S. agalactiae, S. dysgalactiae and S. uberis to detect the major bacterial pathogens in the milk. In all the stages of lactation and age groups $S$. aureus, Streptococcus and E. coli were detected with the predominance of $S$. aureus which is similar to the results of this study in which we too detected Staphylococcus and Streptococcus predominantly. However, they could multiplex S. aureus in their developed multiplex which we could not do. Similarly Amin et al. (2011) collected bovine milk samples from the cases of clinical and sub-clinical mastitis and examined them bacteriologically and by simplex and multiplex PCR assays for detection of Staphylococcus aureus, Escherichia coli and Streptococcus agalactiae. In another study Gandra et al. (2016) detected coagulase positive Staphylococcus (CPS) directly in samples of artificially contaminated milk, using MPCR. They designed primers specific for the nuc gene (NUC1-NUC2 for $S$. aureus, NUC3-NUC4 for S. hyicus and NUC5-NUC6 for $S$. intermedius) and detected three target species by MPCR, directly from bovine whole milk, with adequate specificity and acceptable detection limit for identification of coagulase positive Staphylococcus (CPS) in foods with the detection limit of $10^{3}$ $\mathrm{CFU} / \mathrm{ml}$ which is in contrast to our study as we could not multiplex

Table 1 Primers used in PCR reaction for the detection of different organisms

\begin{tabular}{|c|c|c|c|c|}
\hline S. No. & Organism & Accession No./ & e5' to $3^{\prime}$ & Amplicon Size(bp) \\
\hline \multirow[t]{2}{*}{$\overline{1}$} & Escherichia coli & NC_002695.1 & F:TGTTGGGTTAAGTCCCGCAA & 230 \\
\hline & & & R: CTCCAATCCGGACTACGACG & \\
\hline \multirow[t]{2}{*}{2} & Klebsiella pneumoinae & NC_06845.1 & F:CTGCATTCGAAACTGGCAGG & 187 \\
\hline & & & R: GTTTACGGCGTGGACTACCA & \\
\hline \multirow[t]{2}{*}{3} & Staphylococcus aureus & СР000253.1 & F: GAGCGGGACATGCCCTTTA & 508 \\
\hline & & & R:TGTCCGCCTTTTCTTCTTGC & \\
\hline 4 & Streptococcus agalactiae & NC_004116.1 & $\begin{array}{l}\text { F: CTGTGAGATGGACCTGCGTT } \\
\text { R.ACGCCCAATAAATCCGGACA }\end{array}$ & 352 \\
\hline
\end{tabular}

Table 2 Comparison of three different methods used for the extraction of DNA from milk

\begin{tabular}{|c|c|c|c|c|}
\hline$\overline{\text { S. No. }}$ & $\begin{array}{l}\text { Mastitic milk exhibiting } \\
\text { bacterial growth }\end{array}$ & $\begin{array}{l}\text { No. of samples having } \\
\text { when tested by MPCR }\end{array}$ & $\begin{array}{l}\text { positive DNA } \\
\text { (Per cent) }\end{array}$ & \\
\hline 1. & 50 & $\begin{array}{l}\text { SDS Triton Method } \\
50 / 50(100)\end{array}$ & $\begin{array}{l}\text { Power Food Microbial DNA Kit } \\
30 / 50(60)\end{array}$ & $\begin{array}{c}\text { Milk Bacteria DNA Kit } \\
8 / 50(16)\end{array}$ \\
\hline
\end{tabular}


Fig 1 Single and Mutiplex Polymerase Chain Reaction

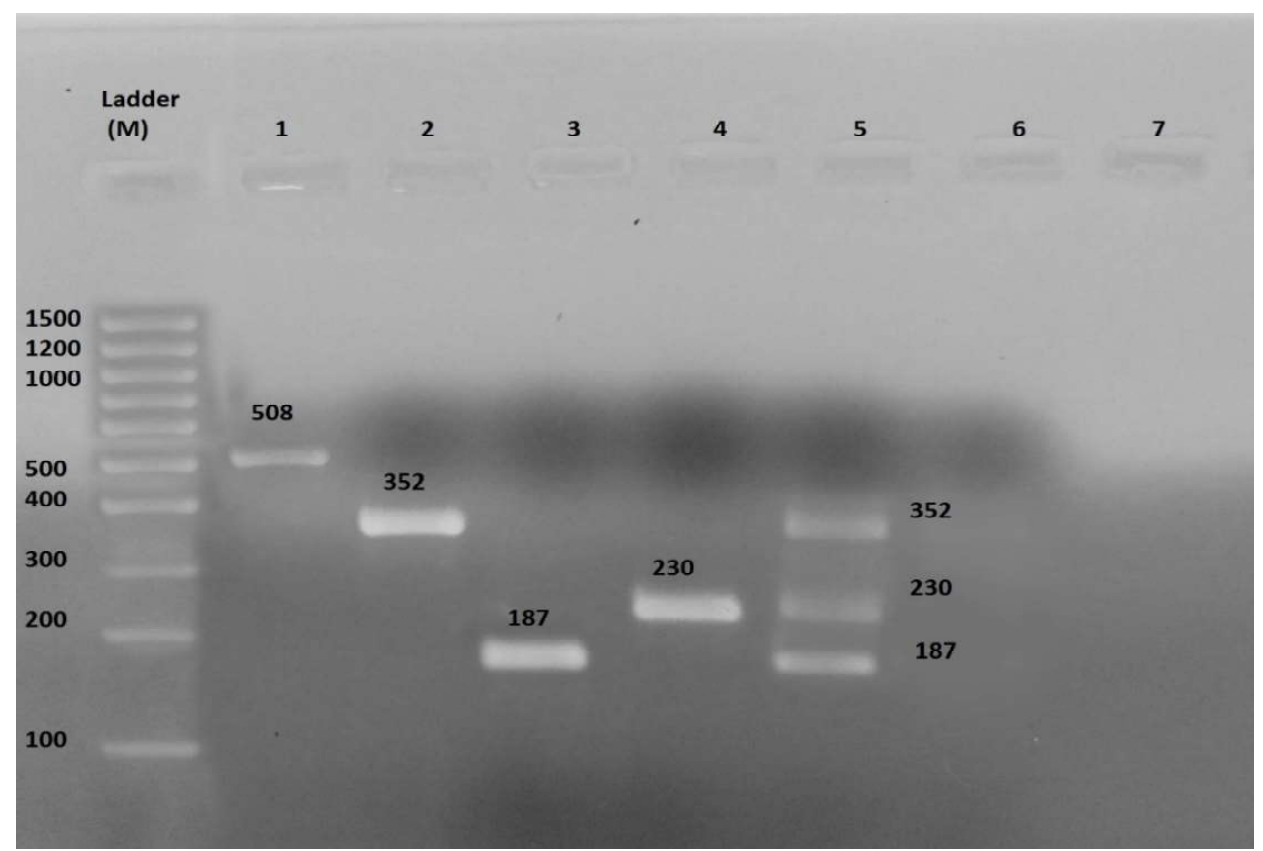

M: 100bp ladder; Lane 1 Staphylococcus (508bp), Lane 2 Streptococcus (352bp), Lane 3 Klebsiella (187), Lane 4 E. coli (230), Lane 5 multiplex PCR for Streptococcus , E. coli and Klebsiella

S. aureus. In the present study, multiplex PCR was developed for Streptococcus, Klebsiella and E. coli but could not include Staphylococcus. One plausible reason might be the cell wall of gram positive bacteria, that contains vide variety of molecules that serve to provide rigid exoskeleton for protection against both mechanical and osmotic lysis. It has been observed that Staphylococcus aureus detection from milk by molecular techniques was reported when lysostaphin a peptidase produced by Streptococcus simulans that break the cellular membrane of Staphylococcus aureus was used in DNA extraction protocol (Chapaval et al., 2008). We too attribute it due to the difference between extraction of DNA from Gram positive and Gram negative or it may be possible that template DNA of Staphylococcus required more sophisticated approach which we did not apply because we wanted to use multiplex directly on field samples. In a similar study Troncarelli et al., (2015) developed a multiplex PCR for Staphylococcus aureus, Streptococcus agalactiae and Escherichia coli in bovine milk samples collected from bulk tanks. Milk samples collected from each bulk tank were evaluated by MPCR and microbiological culture. S. aureus, S. agalactiae and E. coli were isolated by culture in $30 \%, 10 \%$ and $40 \%$ respectively, and detected by MPCR in $0 \%, 10 \%$ and $35 \%$ bulk tank milk samples respectively. They observed that their developed MPCR was $93.2 \%$ specific and $37.5 \%$ sensitive with $78.3 \%$ accuracy. MPCR protocol was efficient for $S$. agalactiae and E. coli detection in the evaluated bulk tank milk samples, but failed to detect $S$. aureus which is absolutely similar to the results of our study where Staphylococcus was positively isolated from the microbiological cultures but failed to amplify with the others organisms in the multiplex reaction. However the exact reason for this could not be identified and need further studies.

Control measures of mastitis in dairy cattle needs sensitive, rapid and specific tests to identify the main bacteria that cause heavy losses in the dairy industry. Hence, from the study it could be concluded that with the help of multiplex PCR we could identify Streptococcus, Klebsiella and E. coli in a single PCR reaction directly on the DNA extracted from the milk.

\section{Acknowledgements}

The authors are grateful to the University Grant Commission (UGC), India for the financial support MRP-MAJOR-VETE-201331898 (General). The authors are also thankful to the Director Research, GADVASU for providing the necessary laboratory facilities.

\section{References}

Amin AS, Hamouda RH, Abdel-All AAA (2011) PCR assays for detecting major pathogens of mastitis in milk samples. World J Dairy and Food Sci 6:199-206

Berri M, Laroucau K, Rodolakis A (2000) The detection of Coxiella burnetii from ovine genital swabs, milk and fecal samples by the use of a single touchdown polymerase chain reaction. Vet Microbiol 72(3): 285-293

Birkenmeyer LG, Mushahwar IK (1991) DNA probe amplification methods. J Virol Methods, 35(2):117-126

\section{Conclusions}


Chapaval L, Moon DH, Gomes JE, Duarte FR, Tsai SM (2008) An alternative method for Staphylococcus aureus DNA isolation. Arq Bras Med Vet Zootec 60:299-306

Gaddi RM, Isloor S, Rathnamma D, Avinash B, Veeregowda BM, Bhaskar $\mathrm{R}$, Rao S (2016) Multiplex-PCR to detect pathogens and analysis of relation of age and stage of lactation of cows to sub-clinical mastitis. $\mathrm{J}$ Exp Biol Agri Sci 4; S59-S68

Gandra EA, Fernandez MA, Silva JA, Silva WPD (2011) Standardization of a multiplex PCR for the identification of coagulase-positive Staphylococcus. Food Sci Technol 31(4): 946-949

Geha DJ, UHL JR, Gustaferro CA, Persing DH (1994) Multiplex PCR for identification of methicillin resistant staphylococci in the clinical laboratory. J Clinical Microbiol 32: 1768-1772

Khan MA, Kim AC, Kakoma I, Morin E, Hansen RD, Hurley WL, Tripathy DN, Baek B K (1998) Detection of Staphylococcus aureus in milk by use of polymerase chain reaction analysis. Am J Vet Res 59(7): 807-813

Kour G, Chandra M, Kaur G, Narang D, Gupta DK, Arora AK, Sharma NS (2017) Prevalence of mastitis causing organism and their antibiotic resistance pattern in dairy farms. Indian J Dairy Sci 70(5): 587-592

Kuang Y, Tani K, Synnott AJ, Ohshima K, Higuchi H, Nagahata H, Tanji $\mathrm{Y}$ (2009) Characterization of bacterial population of raw milk from bovine mastitis by culture-independent PCR-DGGE method. Biochem Eng J 45: 76-81

Lipkin E, Tikoschinsky Y, Arbel R, Sharoni D, Soller M, Friedmann A (1993) Early PCR amplification test for identifying chimerism in female calves co twin to a male in cattle. Anim Biotechnol 4(2):195201

Miller RH, Paape M J, Fulton LA, Schutz MM (1993) The relationship of milk somatic cell count to milk yields for Holstein heifers after first calving. J Dairy Sci 76(3):728-733

Radostitis O, Gay C, Hinchcliff K, Constable P (2006) Veterinary Medicine A Textbook of the Diseases of cattle, horses, sheep, pig and goats WB Saunders, Philadelphia, USA

Ranjan R, Gupta MK, Singh S, Kumar S (2010) Current trend of drug sensitivity in bovine mastitis. Vet World 3:17-20

Sambrook J, Russell DW (2001) Molecular Cloning: A Laboratory Manual. Cold Spring Harbour, Cold Spring Laboratory Press, New York

Shome BR, Mitra SD, Bhuvana M, Krithiga N, Velu D, Shome R, Isloor S, Barbuddhe SB, Rahman H (2011) Multiplex PCR assay for species identification of bovine mastitis pathogens. J Appl Microbiol 11:1349-1356

Troncarelli MZ, Langoni H, Richini-Pereira VB, Marson PM, Silva RC (2015) Accuracy of a multiplex PCR protocol for Staphylococcus aureus, Streptococcus agalactiae and Escherichia coli detection in bulk tanks. Brazilian J Vet Anim Sci 22:625-633

Untergasser A, Cutcutache I, Koressaar T, Ye J, Faircloth B C, Remm M, Rozen SG (2012) Primer 3 new capabilities and interfaces. Nucleic Acids Res 40(15): e115 